Carlos André Stuepp ${ }^{1+}$, Ivar Wendling², Henrique Soares Koehler', Katia Christina Zuffellato-Ribas'

\section{CLONAL FORESTRY OF Piptocarpha angustifolia: SURVIVAL AND GROWTH VIGOR IN FIELD CONDITIONS}

Keywords:

Vassourão-branco

Field evaluation

Forestry of native species

Silviculture

Histórico:

Recebido 10/11/2016

Aceito $28 / 11 / 2016$

Palavras chave:

Vassourão-branco

Avaliação a campo

Espécies florestais nativas

Silvicultura

${ }^{+}$Correspondência: carlosandrehc@hotmail.com
ABSTRACT: Piptocarpha angustifolia is a potential native species for Brazilian forestry. However, a lot of challenges and technical constraints persist, hindering its expansion as a species for forest plantations, among them, the lack of evaluation of their survival and growth in field conditions. Thus, we evaluated the survival and growth vigor of Piptocarpha angustifolia according to two initial heights of mini-cuttings at planting. Plants from mini-cuttings with $20 \pm 5 \mathrm{~cm}$ and $40 \pm 5 \mathrm{~cm}$ were planted in field using $3 \times 2 \mathrm{~m}$ spacing. In these, we evaluated the survival, base diameter and total height during 24 months. The experiment was implemented in a completely randomized design in a split plot model. Plants of $20 \pm 5 \mathrm{~cm}$ are superior in survival to $40 \pm 5 \mathrm{~cm}$ ones. The growth in height and diameter remained constant up to 24 months, reaching $64.1 \mathrm{~cm}$ and 13.5 $\mathrm{mm}$, independently of the plants expedition time. In general, the establishment of clonal plantation of Piptocarpha angustifolia was limited by the attack of pests, mainly cutting ants. For this reason, plantation of this species must take into account the possibility of greater pest control.

\section{SILVICULTURA CLONAL DE Piptocarpha angustifolia: SOBREVIVËNCIA E VIGOR DE CRESCIMENTO A CAMPO}

RESUMO: Piptocarpha angustifolia (vassourão-branco) é uma espécie nativa potencial para a silvicultura brasileira. No entanto, uma série de desafios e limitações técnicas ainda persistem, dificultando sua expansão como espécie para plantios florestais, dentre eles, a falta de avaliação de sua sobrevivência e crescimento em condições de plantio a campo. Assim, o presente estudo objetivou avaliar a sobrevivência e o vigor de crescimento em condições de pleno sol a campo de mudas clonais de Piptocarpha angustifolia em função da altura inicial das mudas, no momento do plantio. Mudas provenientes de miniestaquia com $20 \pm 5 \mathrm{~cm}$ e $40 \pm 5 \mathrm{~cm}$ de altura foram plantadas a campo em espaçamento $3 \times 2$ $\mathrm{m}$. Nestas, foram avaliadas a sobrevivência, o diâmetro da base e a altura total ao longo de 24 meses. $O$ experimento foi conduzido num delineamento inteiramente casualizado, em parcelas subdivididas no tempo. Mudas de $20 \pm 5 \mathrm{~cm}$ mostraram-se superiores em sobrevivência às de $40 \pm 5 \mathrm{~cm}$. $O$ crescimento em altura e diâmetro manteve-se constante até os 24 meses, alcançando $64, \mathrm{l}$ cm e 13,5 mm, independente da altura de expedição das mudas. De modo geral, o estabelecimento de plantios clonais de Piptocarpha angustifolia foi limitado pelo ataque de pragas, principalmente formigas cortadeiras. Por essa razão, a recomendação de plantios desta espécie precisa levar em conta a possibilidade de um maior controle de pragas.

' Federal University of Paraná - Curitiba, Paraná, Brazil

2 Embrapa Florestas - Colombo, Paraná, Brazil 


\section{INTRODUCTION}

Clonal forestry deals with tree selection process, vegetative rescue, genetic and phenotypic analysis, and establishment and management of clonal plantations (SCHULER; MCCARTHY, 20I5). The development of forests with high uniformity, adaptation to environmental changes and especially increased productivity are some of its benefits (XAVIER; SILVA, 20I0; WENDLING et al., 20I5), and cloning is widely applied to the silviculture of Eucalyptus species (XAVIER; SILVA, 2010).

Despite the large number of researches enabling propagation of native species with silvicultural potential (FERRIANI et al., 20I I; DIAS et al., 20I2; WENDLING et al., 20I6), only few researches assess their potential for growth in the field (TONINI et al., 2008; MELOTTO et al., 2009; WENDLING et al., 2016). Some of these species have high economic potential; however, they have limited usage due to the lack of information about their silviculture.

The production of quality clonal plants has been one of the challenges of forestry in native species (KRATZ et al., 20I5). In general, research involving the quality of forest seedlings has focused on improving the shortterm survival and the growth in the field (CORTINA et al., 20I3). One of the important factors influencing survival and vegetative vigor in the field has been the height of seedlings at planting (VILLAR-SALVADOR et al., 2004; JACOBS et al., 2005; REIS et al., 2008). The ideal time for expedition of the seedlings depends directly on the target species and nursery management practices, ranging from 15 to $30 \mathrm{~cm}$ for Eucalyptus spp. (GOMES et al., 1996). However, some authors have identified a higher survival in the field for seedlings with larger aerial parts (VILLARSALVADOR et al., 2004; JACOBS et al., 2005).

Piptocarpha angustifolia Dusén ex Malme (Asteraceae) is an initial secondary species (SEITZ, 1976). It has its occurrence associated with araucaria forests, restricted to higher regions of the South Brazilian plateau, at altitudes between 500 and I,200 m (SEITZ, 1976). It presents orthotropic characteristics, fast growth, high quality wood for various purposes and favorable history of sawing and processing in the wood industry (FOSSATI; NOGUEIRA, 2009). Moreover, its use with dual purpose makes the species even more interesting, allowing the use of degraded areas for silvicultural purposes (SEITZ, 1976).

The lack of information about Piptocarpha angustifolia silviculture has expanded the gap between its economic/ecological potential and its actual application. Currently in Brazil there are no plantations for commercial purposes of the species and the production of seedlings for ecological purposes is scarce due to the limitations noted in its sexual reproduction process (CARVALHO, 2006; FOSSATI; NOGUEIRA, 2009).

Thus, the objective of this study was to evaluate the infield survival and growth potential of Piptocarpha angustifolia plants produced by mini-cuttings with two expedition heights.

\section{MATERIAL AND METHODS}

The experiment was conducted between September 2014 and September 2016 at "Fazenda Canguiri”, located in Pinhais, state of Paraná, Brazil (2523' S and $49^{\circ} 07^{\prime}$ W, 900 m of altitude). According to Köppen's classification, the climate of the region is temperate, $\mathrm{Cfb}$ type, with the coldest month temperature between -3 and $18{ }^{\circ} \mathrm{C}$, always wet with rain well distributed throughout the year and average temperature of the warmest month below $22^{\circ} \mathrm{C}$ (Figure I).

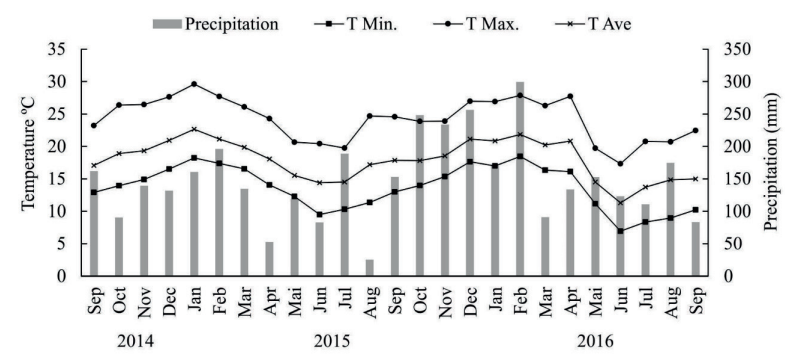

FIGURE I Average of minimum (T Min.), maximum (T Max.) and average ( $T$ Ave) temperatures and precipitation for Pinhais, state of Paraná, Brazil, between the months of September 2014 and September 2016. Source: SIMEPAR/PR.

The experimental area has occurrence of Haplic Cambisol. In terms of chemical properties, the soil has fertility between medium and high (Table I).

TABLE I Clay contents and chemical properties of the experimental area's soil from 0 to $30 \mathrm{~cm}$ and 50 to $80 \mathrm{~cm}$ of depth.

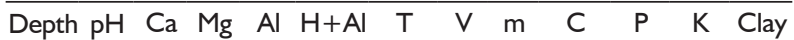
$(\mathrm{cm}) \quad$ - $\quad$------- cmolc. $\mathrm{dm}^{-3}$-------- --- \% --- $\mathrm{g} \cdot \mathrm{dm}^{-3}-\mathrm{mg}^{-\mathrm{dm}^{-3}-} \%$

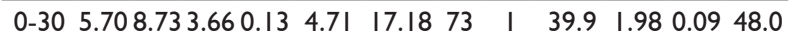

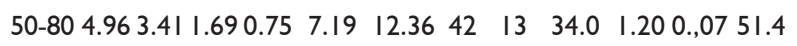

Extractors: Mehlich-I (P and K); and KCl (Ca, Mg and Al).

The plants were produced using mini-cuttings technique (STUEPP et al., 2017), with clonal minigarden formed by plants previously produced by traditional cuttings techniq Growth in diameter and height of Piptocarpha angustifolia clonal plants evaluated at 6, 12, 18 and 24 months after planting in Pinhais, state 
of Paraná, Brazil. Averages followed by the same letter do not differ between them according to the Tukey test at $5 \%$ of probability. ue from epicormic shoots of adult trees, from a remnant of Araucaria Forest in secondary stage of development in the municipality of Petrolândia, state of Santa Catarina $\left(27^{\circ} 44^{\prime}\right.$ S and $50^{\circ} 02^{\prime}$ $\mathrm{W}, 410 \mathrm{~m}$ of altitude). The mini-garden was established in a greenhouse covered with polyethylene, where the mini-stumps received drip fertigation, three times a day at an average flow rate of $6 \mathrm{~L} \cdot \mathrm{m}^{-2} \cdot$ day $^{-1}$ with the nutrient solution described in Stuepp et al. (2017).

Mini-cuttings with $8 \pm 1 \mathrm{~cm}$ in length and average diameter of about $0.5 \pm 0.1 \mathrm{~cm}$ were prepared, keeping up two leaves reduced to $50 \%$ of their original surface. Planting was made in polypropylene tubes with capacity of $280 \mathrm{~cm}^{3}$, filled with carbonized rice husk and vermiculite in the ratio $I: I(v / v)$, about $2 \mathrm{~cm}$ deep. These tubes were placed in a greenhouse (average temperature of $24 \pm 2$ ${ }^{\circ} \mathrm{C}$ and $85 \%$ of relative humidity) for 70 days.

After staying in the greenhouse, the plants were transferred to the shade house (50\% of shading) for a period of 30 days following to the glass-house (for 90 days) and to a full sunlight area (for 30 days) until being sent to the field (Table 2). After 210 days, the plants were sorted in two heights, $20 \pm 5 \mathrm{~cm}$ and $40 \pm 5 \mathrm{~cm}$ (Figure $2 \mathrm{~A}, \mathrm{~B})$ and sent to the field for planting.

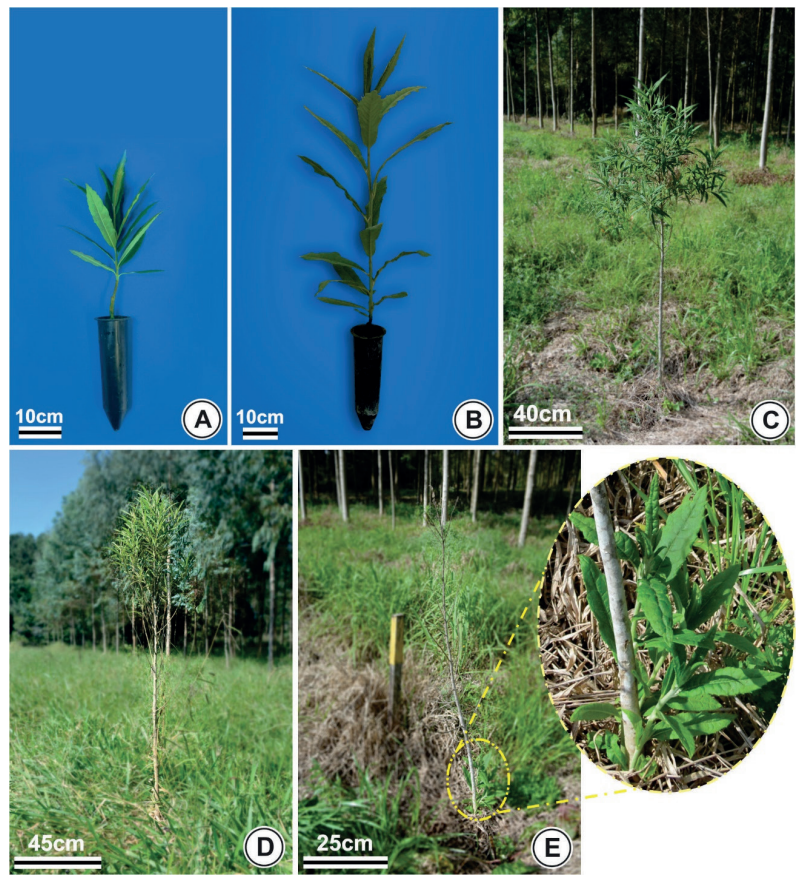

FIGURE 2 General characterizations of the experiment with clonal plants of Piptocarpha angustifolia: A - plants with $20 \pm 5 \mathrm{~cm}$; B - plants with $40 \pm 5 \mathrm{~cm}$; C, D - Plants with satisfactory development; E - Plant attacked by leaf-cutting ants, identified by basal regrowth.
Prior to planting a mechanical mowing was performed in the whole experiment area. The preparation of the area was made by marking the lines with a subsoiler ( $50 \mathrm{~cm}$ deep) at a fixed spacing of $3 \mathrm{~m}$ between lines. Planting was carried out manually using 3 $\times 2 \mathrm{~m}$ spacing, in September 2014. The fertilizating was carried out with $100 \mathrm{~g}$ of NPK (4-14-8) per pit. Postplanting silvicultural treatments consisted of mechanized mowing at 2, 4 and 6 months after planting in the whole area and 12 to 18 months after planting between lines.

The experiment area is an environmental protection area "APA do rio Iraí" (State Decree $N^{\circ}$. I,753/1996) (PARANÁ, 1996) and, consequently, the prior control of leaf-cutting ants was not possible. Throughout the experiment, the survival of plants was evaluated at I, 2, 3, 6, 12, 18 and 24 months after planting, and the base diameter ( $10 \mathrm{~cm}$ of height) and total height were evaluated at $6,12,18$, and 24 months after planting.

The experiment was installed with a completely randomized design, with two treatments related to the height of clonal plants planted in the field $(20 \pm 5 \mathrm{~cm}$ and $40 \pm 5 \mathrm{~cm}$ ) with 5 replicates of 25 plants per experimental unit, totaling 200 plants evaluated, excluding the border.

TABLE 2 Temperature and average humidity in different environments used in the production of Piptocarpha angustifolia mini-cuttings.

\begin{tabular}{|c|c|c|c|c|}
\hline Environment & Temperature I & Humidityl & Irrigation & Fertirrigation2 \\
\hline \multirow[t]{2}{*}{ Greenhouse } & $20^{\circ} \mathrm{C}( \pm 10)$ & $>80 \%$ & $\begin{array}{l}\text { Intermittent } \\
\text { nebulization }\end{array}$ & - \\
\hline & & & $\begin{array}{l}\text { Sprinkling } \\
\text { (I minute, } \\
\text { five times }\end{array}$ & $\begin{array}{c}4 \mathrm{~g} \cdot \mathrm{L}^{-1} \text { urea; } 3 \\
\mathrm{~g} \cdot \mathrm{L}^{-1} \text { normal } \\
\text { superphosphate; } \\
0.25 \mathrm{~g} \cdot \mathrm{L}^{-1} \text { FTE BR I0 }\end{array}$ \\
\hline \multirow[t]{2}{*}{ Shade house } & $18^{\circ} \mathrm{C}( \pm 15)$ & 24 to $95 \%$ & $\begin{array}{l}\text { per day with } \\
\text { flow } \\
\left.97 L^{\prime} \text { hour }{ }^{-1}\right)\end{array}$ & $\begin{array}{c}\text { [7\% Zn, } 4 \% \mathrm{Fe}, 4 \\
\% \mathrm{Mn}, 0.1 \% \mathrm{Mo}, \\
2.5 \% \mathrm{~B}, 0.8 \% \\
\mathrm{Cu}] \text { and } 3 \mathrm{~g} \cdot \mathrm{L}^{-1} \\
\text { potassium chloride } \\
8 \mathrm{~g} \cdot \mathrm{L}^{-1} \text { urea; } 6\end{array}$ \\
\hline & & & $\begin{array}{l}\text { Sprinkling } \\
\text { (I minute, } \\
\text { three times }\end{array}$ & $\begin{array}{c}g \cdot L^{-1} \text { normal } \\
\text { superphosphate; } 0.5 \\
g \cdot L^{-1} \text { FTE BR } 10\end{array}$ \\
\hline Glass-house & $20^{\circ} \mathrm{C}( \pm 18)$ & 20 to $90 \%$ & $\begin{array}{l}\text { per day with } \\
\text { flow } \\
97 \mathrm{~L} \cdot \text { hour }^{-1} \text { ) }\end{array}$ & $\begin{array}{c}\text { [7\% Zn, } 4 \% \mathrm{Fe}, 4 \\
\% \mathrm{Mn}, 0.1 \% \mathrm{Mo} \\
2.5 \% \mathrm{~B}, 0.8 \% \\
\mathrm{Cu}] \text { and } 6 \mathrm{~g} \cdot \mathrm{L}^{-1} \\
\text { potassium nitrate } \\
4 \mathrm{~g} \cdot \mathrm{L}^{-1} \text { ammonium }\end{array}$ \\
\hline Full sunlight & Figure 2 & - & $\begin{array}{c}\text { Sprinkling } \\
(30 \text { minutes, } \\
\text { four times } \\
\text { per day with } \\
\text { flow } \\
\left.97 \mathrm{~L} \cdot \text { hour }^{-1}\right)\end{array}$ & $\begin{array}{c}\text { sulfate; I } \\
\mathrm{g} \cdot \mathrm{L}^{-1} \text { normal } \\
\text { superphosphate; } \\
\text { I } \mathrm{g} \cdot \mathrm{L}^{-1} \mathrm{FTE} \mathrm{BR} \mathrm{I0} \\
{[7 \% \mathrm{Zn}, 4 \% \mathrm{Fe}, 4} \\
\% \mathrm{Mn}, 0.1 \% \mathrm{Mo} \\
2.5 \% \mathrm{~B}, 0.8 \% \\
\mathrm{Cu}] \text { and } 4 \mathrm{~g} \cdot \mathrm{L}^{-1} \\
\text { potassium chloride }\end{array}$ \\
\hline
\end{tabular}

'The control of temperature and humidity only occurred in the greenhouse; ${ }^{2}$ The fertigation at all stages were performed at intervals of 7 days. Source: Laboratory of Forest Species Propagation, Embrapa Forests, Colombo-PR, Brazil. 
The homogeneity of the data was evaluated through the Bartlett test and later through the ANOVA statistical test, using a split-plot model. In situations of statistical significance $(p<0.05)$, the variables were analyzed through the Tukey test at $5 \%$ of probability.

\section{RESULTS AND DISCUSSION}

The average survival of Piptocarpha angustifolia plants, after 24 months of evaluation in the field did not exceed $28 \%$ (Figure 3 ). In part, these results are consequences of the action of pests, mainly leaf-cutting ants, checking the damage throughout the entire evaluation period.

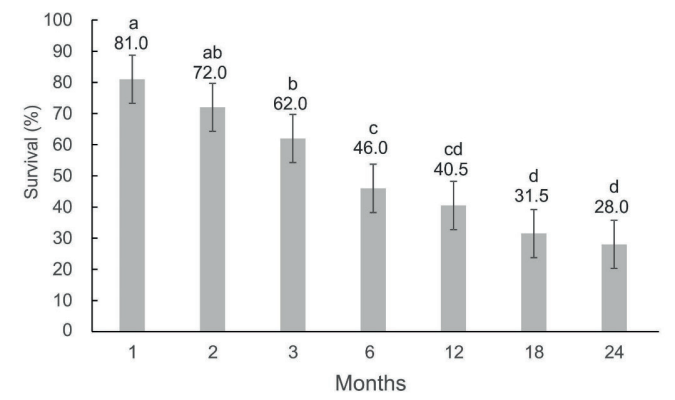

FIGURE 3 Survival of Piptocarpha angustifolia clonal plants evaluated at I, 2, 3, 6, 12, 18 and 24 months after planting in Pinhais, state of Paraná, Brazil. Averages followed by the same letter do not differ between them according to the Tukey test at $5 \%$ of probability.

The growth in diameter and the height of the plants remained constant until 24 months without the existence of peaks throughout the experimental period (Figure 4). These two variables have been strongly influenced by pests attack during the experiment; in some cases, the whole stem dried in one assessment and the sprouting of new basal shoots in the next assessment was observed (Figure 2 E). In addition,

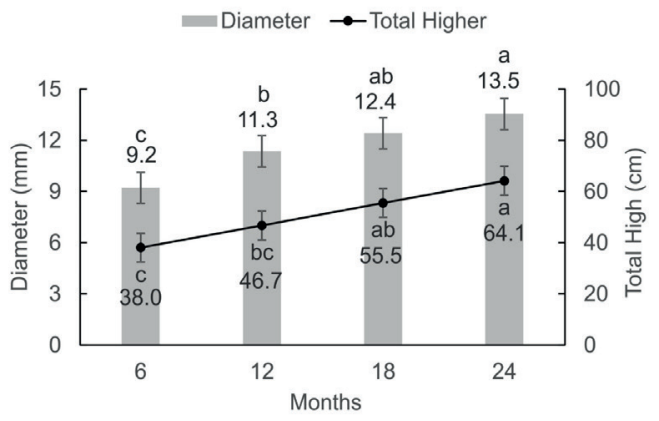

FIGURE 4 Growth in diameter and height of Piptocarpha angustifolia clonal plants evaluated at 6, 12, 18 and 24 months after planting in Pinhais, state of Paraná, Brazil. Averages followed by the same letter do not differ between them according to the Tukey test at $5 \%$ of probability. due to lack of commercial plantations of the species in Brazil, information regarding the incidence of pests and diseases do not exist in the literature, making it difficult to estimate the risk of establishment of plantations with the species. Damages caused by insects are commonly seen in forest plantations, generating significant changes in the morphological characteristics of the root and aerial parts of plants (KLAPWIJK et al., 2016).

Although described as a kind of high vegetative vigor (SEITZ, 1976; FOSSATI; NOGUEIRA, 2009), clonal plants of Piptocarpha angustifolia presented in all assessments reduced increases in diameter and height (Figure 4). These results expose the effect generated by the constant attack of pests, with consequences that go beyond the reduction of photosynthetic capacity (CANTARELLI et al., 2008). Plants have an elaborate defense system to resist the attack of herbivore insects, mainly involving two hormone classes, ethylene and jasmonic acid (O'DONNELL et al., 1996). Once attacked, the energy and nutritional demand from photosynthesis is directed to the defense system at the expense of vegetative growth (ZAVALA et al., 2004; WU; BALDWIN, 2010). This effect is evident in the stagnation of the growth of clonal plants of Piptocarpha angustifolia that presents symptom of pest attack in the field.

The successive leaf-cutting ant attacks in the field not only caused the stagnation of the growth of the attacked plants, but also broke the apical dominance. Cutting or girdling the apical meristem is a damage that alters the hormonal balance, resulting in the blockage of auxin basipetal transport (WAN et al., 2006), along with increasing concentrations of cytokinin translocated by the roots, resulting in the initiation of dormant buds below the affected area (RASMUSSEN et al., 20I0), as found in this research (Figure $2 \mathrm{E}$ ).

The low adaptation to local and to experimental conditions of Piptocarpha angustifolia in the experiment also can be one of the factors responsible for their reduced survival rate (MENESES FILHO et al., 1995). Little is known about their requirements, especially in the initial stage of development. Piptocarpha angustifolia seedlings under shade conditions reached up to $170 \mathrm{~cm}$ after 12 months, while those conducted in full sunlight had an average height of $40 \mathrm{~cm}$ (SEITZ, 1976). The author also identified the ombrophilous characteristic of this species in the initial stages of development, associated with preference for less exposition to sunlight slopes.

The highest growth of Piptocarpha angustifolia seedlings, under shade conditions highlighted by Seitz (1976), probably covers only the initial stages of the 
species growth, since, once it is acclimatized to the full sunlight conditions, it can develop as a traditional heliophytic species, as its successional classification suggests (CARVALHO, 2006). This hypothesis was verified in this study for plants that did not suffer damage by insects, satisfactorily expressing their growth potential, with up to $1.86 \mathrm{~m}$ in height and $22 \mathrm{~mm}$ in diameter 24 months after planting (Figure $2 \mathrm{C}, \mathrm{D}$ ).

Regarding the height of mini-cuttings for expedition in the field, the average survival after 24 months was significantly superior for those of $20 \pm 5 \mathrm{~cm}$ (57.6\%) compared to the $40 \pm 5 \mathrm{~cm}(45.6 \%)$ ones. The aerial part height is a much applied characteristic to determine the quality of forest seedlings (GOMES et al., 2002), mainly related to the survivability in the field. Determining the optimum height for planting forest seedlings varies according to species and even to the same species in different environments (VILLAR-SALVADOR et al., 2004; JACOBS et al., 2005). On the other hand, when considering the production cost of forest seedlings, those with $20 \pm 5 \mathrm{~cm}$ are produced in a shorter time, thereby reducing costs and the cycle (SIMÕES et al., 20I2).

The lower survival of plants with $40 \pm 5 \mathrm{~cm}$ may be associated with herbaceous condition of their upper third part, responding to water stress with the withering of the apical part. However, the lower leaf surface of the plants with $20 \pm 5 \mathrm{~cm}$ may have reduced water loss through transpiration. A similar trend was reported for Quercus ilex, considering the smaller size of the seedlings a drought-resistance characteristic (LLORET et al., 1999).

Another factor that may have favored the best performance of plants with $20 \pm 5 \mathrm{~cm}$ is their largest root/ aerial part ratio, resulting in higher capacity for mantainning the growth of these plants in comparison to those with larger size. This relation shows the balance between these two parts in the search for nutrients and water (VANDRESEN et al., 2007), being an excellent variable for predicting the performance of these plants in the field (WEBER et al., 20I5). Similarly, plants with greater root/ aerial part ratio are considered more likely for plantations in dry environments (MOKANY et al., 2006).

\section{CONCLUSIONS}

Clonal plants of $20 \pm 5 \mathrm{~cm}$ are suitable for clonal plantations of Piptocarpha angustifolia, favoring their survival in the field. The growth in height and diameter in the field is not influenced by the height of the original plants. Further studies are needed to determine the species' behavior in conditions of full sunlight in homogeneous plantations, as well as their susceptibility to attack by leaf-cutting ants.

\section{ACKNOWLEDGMENTS}

To the Brazilian Agricultural Research Corporation (Embrapa Florestas). To "Fazenda Canguiri" (UFPR) for technical support and "Núcleo de Inovação Tecnológica em Agropecuária” (NITA-UFPR) for providing the study area. To "Sistema Meteorológico do Paraná" (SIMEPAR) for making available the data regarding temperature and humidity for Pinhais, state of Paraná, Brazil.

\section{REFERENCES}

CANTARELLI, E. B.; COSTA, E. C.; PEZZUTTI, R.; DA SILVA OLIVEIRA, L. Quantificação das perdas no desenvolvimento de Pinus taeda após o ataque de formigas cortadeiras. Ciência Florestal, v. I8, n. I, p. 39-45, 2008.

CARVALHO, P. E. R. Vassourão-Branco. Colombo: Embrapa Florestas, 2006. 6 p. (Embrapa Florestas. Circular técnica II 5).

CORTINA, J.; VILAGROSA, A.; TRUBAT, R. The role of nutrients for improving seedling quality in drylands. New Forests, v. 44, p. 719-732, 2013.

DIAS, P. C. et al. Estaquia e miniestaquia de espécies florestais lenhosas do Brasil. Pesquisa Florestal Brasileira, v. 32, n. 72, p. 453-462, 2012.

FERRIANI, A. P.; ZUFFELLATO-RIBAS, K. C.; HELM, C. V.; BOZA, A.; WENDLING, I.; KOEHLER, H. S. Produção de brotações e enraizamento de miniestacas de Piptocarpha angustifolia. Pesquisa Florestal Brasileira, v. 31, n. 67, p. 257-264, 20I I

FOSSATI, L. C.; NOGUEIRA, A. C. Qualidade física e fisiológica das cipselas de Piptocarpha angustifolia Dusén ex Malme de diferentes populações e árvores porta sementes. Revista Floresta, v. 39, n. 2, p. 419-430, 2009.

GOMES, J. M.; COUTO, L.; LEITE, H. G.; XAVIER, A.; GARCIA, S. L. R. Parâmetros morfológicos na avaliação da qualidade de mudas de Eucalyptus grandis. Revista Árvore, v. 26, n.6, p. 655-664, 2002.

GOMES, J. M.; PAIVA, H. N.; COUTO, L. Produção de mudas de eucalipto. Informe Agropecuário, v. 18, n. I85, p. 15-23, 1996.

JACOBS, D. F; SALIFU, K. F.; SEIFERT, J. R. Relative contribution of initial root and shoot morphology in predicting field performance of hardwood seedlings. New Forests, v. 30, n. 2-3, p. 235-25I, 2005.

KLAPWIJK, M. J.; BYLUND, H.; SCHROEDER, M.; BJÖRKMAN, C. Forest management and natural biocontrol of insect pests. Forestry, v. 89, n. 3, p. 253-262, 2016.

KRATZ, D.; WENDLING, I.; PIRES, P. P.; STUEPP, C. A. Enraizamento de miniestacas de erva mate em substratos a base de casca de arroz e fibra de coco. Revista Floresta, v. 45 , n. 3, p. 609-616, 2015. 
LLORET, F.; CASANOVAS C.; PEÑUELAS, J. Seedling survival of Mediterranean shrubland species in relation to root: shoot ratio, seed size and water and nitrogen use. Functional Ecology, v.13, p. 210-216, 1999.

MELOTTO, A.; NICODEMO, M. L.; BOCCHESE, R. A.; LAURA, V. A.; GONTIJO NETO, M. M.; SCHLEDER, D. D.; SILVA, V. D. Sobrevivência e crescimento inicial em campo de espécies florestais nativas do Brasil Central indicadas para sistemas silvipastoris. Revista Árvore, v. 33, n. 3, p. 425-432, 2009.

MENESES FILHO, L. D. L.; FERRAZ, P. D. A.; PINHA, L.; BRILHANTE, N. Comportamento de 24 espécies arbóreas tropicais madeireiras introduzidas no Parque Zoobotânico Rio Branco-Acre. Rio Branco: Universidade Federal do Acre; I995. v. I, p. 77-8I.

MOKANY, K.; RAISON, R.; PROKUSHKIN, A. S. Critical analysis of root: shoot ratios in terrestrial biomes. Global Change Biology, v. I2, n. I, p. 84-96, 2006.

O'DONNELL, P. J. O.; CALVERT, C.; ATZORN, R.; WASTERNACK, C. H. M. O. Ethylene as a signal mediating the wound response of tomato plants. Science, v. 274, n. 5294, p. 1914, 1996.

PARANÁ. Decreto № I.753, de 06 de maio de 1996. Instituída a Área de Proteção Ambiental na área de manancial da bacia hidrográfica do rio Iraí, denominada APA Estadual do Iraí. Curitiba. Diário Oficial $N^{\circ}$ 4.750. 06 maio 1996.

RASMUSSEN, H. N.; VEIERSKOV, B.; HANSEN-MØLLER, J.; NØRB/EK, R. 'Lateral control': phytohormone relations in the conifer treetop and the short-and long-term effects of bud excision in Abies nordmanniana. Journal of Plant Growth Regulation, v. 29, p. 268-279, 2010.

REIS, E. R.; LÚCIO, A. D. C.; FORTES, F. O.; LOPES, S. J.; DA SILVEIRA, B. D. Período de permanência de mudas de Eucalyptus grandis em viveiro baseado em parâmetros morfológicos. Revista Árvore, v. 32, n. 5, p. 809-814, 2008.

SCHULER, J. L.; MCCARTHY, W. Development of eastern cottonwood cuttings as modified by cutting length and surface area available for rooting. New Forests, Dordrecht, v. 46, n. 4, p. 547-549, 2015.

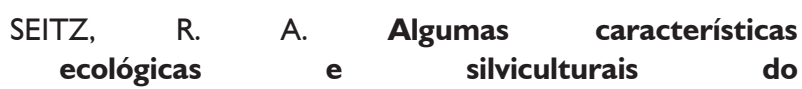
vassourão-branco (Piptocarpha angustifolia Dusén ex Malme). Il 4 f. Dissertação (Mestrado em Ciências) - Setor de Ciências Agrárias, Universidade Federal do Paraná, Curitiba, 1976.

SIMÕES, D.; DA SILVA, R. B. G.; DA SILVA, M. R. Composição do substrato sobre o desenvolvimento, qualidade e custo de produção de mudas de Eucalyptus grandis Hill ex Maiden $\times$ Eucalyptus urophylla ST Blake. Ciência Florestal, v. 22, n. I, p. $91-100,2012$.
STUEPP,C.A.;WENDLING, I.; KOEHLER, H.S.;ZUFFELLATORIBAS, K. C. Successive cuttings collection in Piptocarpha angustifolia mini-stumps: effects on maturation, root formation and root vigor. Acta Scientiarum. Agronomy, 2017. No Prelo.

TONINI, H.; DE OLIVEIRA JUNIOR, M. M. C.; SCHWENGBER, D. Crescimento de espécies nativas da Amazônia submetidas ao plantio no estado de Roraima. Ciência Florestal, v. I8, n. 2, p. I5I-I58, 2008.

VANDRESEN, J.; NISHIDATE, F. R.; TOREZAN, J. M. D.; ZANGARO, W. Inoculação de fungos micorrízicos arbusculares e adubação na formação e pós-transplante de mudas de cinco espécies arbóreas nativas do sul do Brasil. Acta Botanica Brasilica, v. 2 I, n. 4, p. 753-765, 2007.

VILLAR-SALVADOR, P.; PLANELLES, R.; ENRIQUEZ, E.; RUBIRA, J. P. "Nursery cultivation regimes, plant functional attributes, and field performance relationships in the Mediterranean oak Quercus ilex L." Forest Ecology and Management, v. 196, n. 2-3, p. 257-266, 2004.

WAN, X.; LANDHÄUSSER, S. M.; LIEFFERS, V. J.; ZWIAZEK, J. J. Signals controlling root suckering and adventitious shoot formation in aspen (Populus tremuloides). Tree Physiology, v. 26, p. $681-687,2006$.

WEBER, J. C.; MONTES, C. S.; KALINGANIRE, A.; ABASSE, T.; LARWANOU, M. Genetic variation and clines in growth and survival of Prosopis africana from Burkina Faso and Niger: comparing results and conclusions from a nursery test and a long-term field test in Niger. Euphytica, v. 205, n. 3, p. 809-82I, 2015.

WENDLING, I.; WARBURTON, P. M.; TRUEMAN, S. Maturation in Corymbia torelliana $\times C$. citriodora stock plants: effects of pruning height on shoot production, adventitious rooting capacity, stem anatomy, and auxin and abscisic acid concentrations. Forests, v. 6, p. 3763-3778, 2015.

WENDLING, I.; STUEPP, C. A.; ZUFFELLATO-RIBAS, K. C. Araucaria clonal forestry: types of cuttings and mother tree sex in field survival and growth. Revista Cerne, v. 22, n. I, p. 19-26, 2016.

WU, J.; BALDWIN, I. T. New insights into plant responses to the attack from insect herbivores. Annual review of genetics, v. 44, p. I-24, 2010.

XAVIER, A.; SILVA, R. L. Evolução da silvicultura clonal de Eucalyptus no Brasil. Agronomía Costarricense, v. 34, n. I, p. 93-98, 2010.

ZAVALA, J. A.; PATANKAR, A. G.; GASE, K.; HUI, D.; BALDWIN, I. T. Manipulation of endogenous trypsin proteinase inhibitor production in Nicotiana attenuata demonstrates their function as antiherbivore defenses. Plant Physiology, v. I34, n. 3, p. I I8I-I I 90, 2004. 